\title{
Respect and equality as priority values for teaching on Physical Education: perspective of university students \\ Respeto e igualdad como valores prioritarios para la enseñanza de la Educación Física: perspectiva de los universitarios
}

\author{
Lilyan Vega-Ramírez, María Alejandra Ávalos-Ramos, Gladys Merma-Molina
}

Universidad de Alicante (España)

\begin{abstract}
Education is not only concerned with the transmission of knowledge; it must also concern itself with the social and moral development of adolescents. Physical activity and sport provide a favorable environment for promoting personal and social values in adolescents. The aims of the study are, to identify which values are developed and strengthened in High School physical education classes, under the vision of Physical Activity Sciences students, and to develop, implement, and evaluate teaching-learning games activities in the initial training of Physical Activity Sciences students for the integration of values in physical education. The participant group consisted of 87 students belonging to the Degree in Physical Activity and Sport Sciences. The tools used to identify the values was questionnaire designed from list of values presented by Schwartz. The assessment of the design and implementation of the activities was carried out through a rubric. The results confirm that university students would enhance in a future professional the values of respect, equality, and good manners. Regarding gender, it should be noted that there is a significant difference in the chosen values of humility $(p=.016$ ), group work ( $p=$ $.05)$, and empathy $(p=.027)$. Due to the design of the games developed by students, it was concluded that it is more feasible to implement activities that promote the values of collaboration and creativity. It did not happen with the values of equality, perseverance, respect, aggressiveness, authority, and daring; despite them being present in sports activities, they are not easy to focus upon in the objective set.
\end{abstract}

Keywords: gender; physical education; teacher training; sport, social skills.

Resumen. La educación no solo se ocupa de la transmisión de conocimientos; también debe preocuparse por el desarrollo social y moral de los adolescentes. La actividad física y el deporte proporcionan un entorno propicio para la promoción de los valores personales y sociales en los adolescentes. Los objetivos del estudio son identificar qué valores se deberían desarrollar y fortalecer en las clases de educación física, bajo la visión de los estudiantes de Ciencias de la Actividad Física, y diseñar, implementar y evaluar actividades de juego para la integración de los valores en Educación Física en la formación inicial de los alumnos. El grupo participante estuvo formado por 87 estudiantes del grado en Ciencias de la Actividad Física y el Deporte. La herramienta utilizada para identificar los valores fue un cuestionario diseñado a partir de la lista de valores presentada por Schwartz. La valoración del diseño y la implementación de las actividades se llevó a cabo mediante una rúbrica. Los resultados confirman que los universitarios potenciarán en un futuro profesional los valores de respeto, igualdad y buena educación. En cuanto al género, cabe señalar que existe una diferencia significativa en los valores elegidos de humildad $(p=.016)$, trabajo en grupo $(p=.05)$ y empatía $(p=.027)$. Con el diseño de los juegos desarrollados por los estudiantes, se concluyó que es más factible implementar actividades que promuevan los valores de colaboración y creatividad. No ocurrió lo mismo con los valores de igualdad, perseverancia, respeto, agresividad, autoridad y atrevimiento que, a pesar de estar presentes en actividades deportivas, no son fáciles de enmarcar en el objetivo planteado.

Palabras clave: género; educación física; formación docente; deporte; habilidades sociales.

\section{Introduction}

In recent decades, society has been plunged into a deep moral crisis which has generated great concern about the lack or transformation of values in all areas of society (Abella, Lezcano, \& Casado, 2017; Almacelles,

Fecha recepción: 01-11-20. Fecha de aceptación: 08-04-21

María Alejandra Ávalos-Ramos

sandra.avalos@ua.es
2013). This situation also makes way for academic and educational discourse, with problems of racism, xenophobia, and violence, among others, in some classrooms in European countries (Sánchez et al., 2019), leading to the conclusion that it is a priority to propose a reform of the pedagogical paradigm that promotes civic and moral formation.

While it is common to hear that the ultimate purpose of European education policies is not only the transmission of knowledge but also the formation of 
adolescent social and moral development (Agúndez, 2015; Jacobs, Knoppers, \& Webb, 2013), these are still far from promoting authentic moral and ethical education; the plurality of society, the axiological concepts, and the role of the family sometimes hinder such education's development (Agúndez, 2015). Moral recovery remains a discourse that is often confused with the imposition of authority, order, and obedience and is only present in curriculum planning figuratively and not practically (Martínez et al., 2014). From the United Nations Organization and United Nations Educational, Scientific and Cultural Organization international agencies, education plans are promoted to transform lives - for example, the 2030 Agenda the main objectives of which set out to ensure quality, equitable, inclusive education that promotes learning throughout life, with it being of paramount importance to promote the values that are part of national culture, citizenship, and legislation (Núñez \& Bermúdez, 2019).

In the field of physical activity and sports, there is widespread recognition that physical activities provide a favorable environment to promote in adolescents such personal values as empathy, autonomy, and respect (Sánchez, Leo, Sánchez, Gómez, \& García, 2011) and such social values as cooperation, a sense of belonging to a community, and conflict negotiation skills (Larson \& Silverman, 2005; Sánchez-Alcaraz, López-Jaime, Valero-Valenzuela, \& Gómez-Mármol, 2017; Sandford, Armour, \& Duncombe, 2007). Teaching social skills through sports practice could contribute positively to the process of comprehensive student training as these skills include effort, cooperation, and problem solving (Gutiérrez, Escartí, \& Pascual, 2011; Sánchez et al., 2019). There is also evidence that physical and sporting activity contributes to the development of maturity, moral reasoning, orientation to the task, and prosocial behaviors (McHale et al., 2005). At the affective and educational level, researchers such as Ávalos, Martínez, and Merma (2015), Larson (2000), Nyberg and Larsson (2016), Mahoney, Larson, Eccles, and Lord, (2005), Monjas, Ponce, and Gea, (2015), Smith (2003), and Thorburn and Stolz (2017) argue that sports provide opportunities to improve emotional balance, increase self-esteem, hone interpersonal relationship skills to build relationships with peers, and improve academic competencies. However, sport alone does not educate, nor does it guarantee that certain techniques mastered through the development of fitness and motor skills will involve a component of value education by themselves (Hartmann, Sullivan, \& Nelson, 2012; Rubio-Rodríguez,
Hernández, \& Varón, 2019).

Therefore, an intervention is needed that includes systematized lines of action that enable the promotion of value education through physical activity (Brunelle, Danish, \& Forneris, 2007; Sánchez-Alcaraz et al., 2017).

Authors such as Beni, Fletcher and Ní Chróinín, (2017), Escartí, Wright, Pascual, and Gutiérrez (2013), Jacobs, Knoppers, and Webb, (2013), Mikalsen and Lagestad (2020), and Ruiz et at. (2006) argue that it is necessary to take advantage of the formative opportunities offered by physical education (PE), coupled with the position that sport can be a transmitting agent of values. For this reason, it is essential to intervene through educational programs of physical activity and sports that promote personal and social responsibility (Balcázar, 2021; Molina, Gutiérrez, Segovia, \& Hopper, 2020; Pozo, Grao-Cruces, \& Pérez-Ordás, 2018; Prat, Camerino, Castañer, Andueza, \& Puigarnau, 2019), fostering in young people values such as self-control, effort, personal improvement, and leadership, which increase their decision-making capacity both in the educational center and outside it (Escartí, Buelga, Gutiérrez, \& Pascual, 2009; Hellison \& Martinek, 2006; Madrid, Prieto, Samalot, \& Gil, 2016; Monjas et al., 2015; Sánchez et al., 2019). All this certainly implies adequate vocational training of the teacher.

Thornberg (2008) argued that PE teachers are generally unable to reflect critically on their attitudes around value education in the classroom. In this line, Jacobs, Knoppers, and Webb (2013) added that teachers lack sufficient knowledge in the didactics of moral and social development; this may be because teachers receive, in their university education, poor training in securities education (Bergdahl, 2006; Frånberg, 2006). Consequently, value education in $\mathrm{PE}$ seems to fall within the realm of the hidden curriculum, and there is little in the literature about what values students really should learn (Thornberg, 2008) and their importance in sports decision-making (Lee, Whitehead, Ntoumains, \& Hatzigeorgiadis, 2008).

Based on the above premises, this study has the following objectives:

1) To identify what values of Physical Activity and Sport Science (PASS) university students would enhance, in the subject of PE, and whether there are gender differences.

2) To develop, implement, and evaluate teachinglearning activities in the initial training of PASS students for the integration of values in PE. 


\section{Method}

The focus of this study was quantitative and instrument contains three evaluation criteria: achievement of objectives, content, and the development process (Table 2).

exploratory. The participant group was intentional and consisted of 87 students (73 men and 14 women) enrolled in the subject of Programming and Curriculum Design in teaching in PE in the 3rd of the Degree in Physical Activity and Sport Sciences (Spanish university), in the academic year 2018-2019.

\section{Instruments}

Table 2.

\begin{tabular}{|c|c|c|c|c|}
\hline Criteria & Excellent & Good & Insufficient & Poor \\
\hline Objectives & $\begin{array}{l}\text { Adapted and related to } \\
\text { the objective of the } \\
\text { session, they are raised in } \\
\text { a clear and precise way, } \\
\text { allowing participants to } \\
\text { know where the activity i } \\
\text { going and what is } \\
\text { expected of them. }\end{array}$ & $\begin{array}{l}\text { Adapt and relate in some way } \\
\text { to the purpose of the session, } \\
\text { mostly allowing participants } \\
\text { to know where the activity is } \\
\text { isgoing and what is expected of } \\
\text { them. }\end{array}$ & $\begin{array}{l}\text { Somewhat confusing and } \\
\text { partially fit and relate to the } \\
\text { purpose of the session; they do } \\
\text { not clearly let participants } \\
\text { know where the activity is } \\
\text { going and what is expected of } \\
\text { them. }\end{array}$ & $\begin{array}{l}\text { Unclear and do not fit or } \\
\text { relate to the purpose of } \\
\text { the session; they do not } \\
\text { allow participants to } \\
\text { know where the activity } \\
\text { is going and what is } \\
\text { expected of them. }\end{array}$ \\
\hline Content & $\begin{array}{l}\text { Correctly proposes and } \\
\text { names all components of } \\
\text { the activity (information, } \\
\text { objective rules). }\end{array}$ & $\begin{array}{l}\text { Correctly proposes and name } \\
\text { most components of the } \\
\text { activity (information, } \\
\text { objective rules). }\end{array}$ & $\begin{array}{l}\text { sCorrectly proposes and names } \\
\text { only a few components of the } \\
\text { activity (information, objective } \\
\text { rules). }\end{array}$ & $\begin{array}{l}\text { Names not all } \\
\text { components of the } \\
\text { eactivity (information, } \\
\text { objective rules). }\end{array}$ \\
\hline Developm & $\begin{array}{l}\text { Uses the most appropriat } \\
\text { tinstructions and rules for } \\
\text { game development. }\end{array}$ & $\begin{array}{l}\text { eUses instructions and rules } \\
\text { needed for game } \\
\text { development. }\end{array}$ & $\begin{array}{l}\text { Uses instructions and rules that } \\
\text { are appropriate for game } \\
\text { development. }\end{array}$ & $\begin{array}{l}\text { tUses instructions and } \\
\text { rules that confuse game } \\
\text { development. }\end{array}$ \\
\hline
\end{tabular}

The questionnaire of values was designed from list of values presented by Schwartz (1992, 1994). The instrument has 43 items and was adapted to the contextual reality of the participants (Table 1). Each was valued via a Likert scale where 5 indicates «extremely important»(EI), 4 «very important»(VI), 3 «considerable important» (CI), 2 «important» (I), 1 «less important» (LI), 0 «not important» (NI), and -1 «opposite to value (antivalue)» (OV). At the beginning of the questionnaire, the following question was asked: What values do you think should be boosted in PE classes?

The reliability test was carried out, for consistency internal, from the questionnaire of values with a Cronbach's Alpha to 0.72 .

\begin{tabular}{|c|c|c|}
\hline \multicolumn{3}{|r|}{ tude Questionnaire (1994). } \\
\hline Domain & $\begin{array}{l}\text { Conceptualization } \\
\text { Respect commitment accentance of customs }\end{array}$ & Values \\
\hline Tradition & $\begin{array}{l}\text { Respect, commitment, acceptance of customs } \\
\text { and ideas provided by culture. }\end{array}$ & Respect, teamwork, collaboration. \\
\hline Universalism & $\begin{array}{l}\text { Comprehension, appreciation, tolerance, and } \\
\text { protection of the well-being of all people. }\end{array}$ & Equality, social justice. \\
\hline Accordance & $\begin{array}{l}\text { Restriction of actions, inclinations, and impulses } \\
\text { that can alter or harm others and violate social } \\
\text { expectations or norms. }\end{array}$ & $\begin{array}{l}\text { Good manners, discipline, } \\
\text { obedience. }\end{array}$ \\
\hline Achievement & $\begin{array}{l}\text { Seeking personal success by demonstrating } \\
\text { competencies but developed according to social } \\
\text { standards. }\end{array}$ & $\begin{array}{l}\text { Being motivated, successful, } \\
\text { mature, daring, capable. }\end{array}$ \\
\hline Benevolence & $\begin{array}{l}\text { Seeking to preserve and improve the well-being } \\
\text { of those with whom one is in frequent personal } \\
\text { contact, the group of friends, relatives, family. }\end{array}$ & $\begin{array}{l}\text { Being honest, not spiteful, } \\
\text { empathetic, feeling, friendly, loyal, } \\
\text { responsible, punctual, helpful. }\end{array}$ \\
\hline Hedonism & $\begin{array}{l}\text { Relates to pleasure and sensual gratification for } \\
\text { oneself. Enjoying life and self-communities. }\end{array}$ & $\begin{array}{l}\text { Enjoying the class, taking care of } \\
\text { one's physical aspect. }\end{array}$ \\
\hline Self-direction & $\begin{array}{l}\text { Security, independence, choice of one's own } \\
\text { goals. }\end{array}$ & $\begin{array}{l}\text { Trust, freedom, creativity, } \\
\text { independence, moderation, } \\
\text { openness, daring, choosing your } \\
\text { own goals, curiosity, self-control, } \\
\text { will, intelligence. }\end{array}$ \\
\hline Stimulus & $\begin{array}{l}\text { Focuses on emotion, the new, and seeking } \\
\text { challenges in life. }\end{array}$ & Perseverance, aggressiveness. \\
\hline Power & $\begin{array}{l}\text { Has as its axis social status and prestige, control } \\
\text { and dominance over people and resources. }\end{array}$ & Authority, ambition. \\
\hline Tradition & $\begin{array}{l}\text { Implies respect, commitment, and acceptance of } \\
\text { the customs and ideas that culture or religion } \\
\text { provides. }\end{array}$ & Humility. \\
\hline Security & $\begin{array}{l}\text { Absence of risk, harmony and stability of oneself } \\
\text { and relationships. }\end{array}$ & Health, cleanliness. \\
\hline
\end{tabular}

\section{Game Analysis Rubric}

The assessment of collaborative games created by students to promote the acquisition of values in PE classes was performed using Game Analysis Rubric, which was designed and elaborated by three expert teachers. The

\section{Procedure}

The educational experience was realized in the following phases:

\section{First Phase: Educational immersion}

To research educational values, on-site dives were carried out in schools; the activity was carried out in 64 public centers of Compulsory Secondary Education in the province of Alicante (Spain). The selection of schools was made through for convenience and availability. Each college student participated in six immersions in six PE sessions on different days over the course of three weeks. All students carried an observation sheet on aspects of the organization of the class (groups, materials, and space) and on the behavior of the students.

Second Phase: Assessment and analysis of immersions

Subsequently, after the search process was completed, PASS students provided their responses to the list of values selected from Schwartz (1992, 1994), which were given via the online application of the virtual campus of the university. The information collection instrument was available for one week.

The data collected were structured and analyzed using the SPSS 26.0 statistical package for Windows, using descriptive statistics, contingency tables, and MannWhitney's $U$ statistic for non-parametric data.

Third Phase: Design and implementation of workshops in Curriculum Programming and Design in PE Teaching

Once the data were analyzed, two workshops were designed: the first with the aim of studying the concept of values in the field of Physical Activity Sciences, and the second to use teaching strategies for the incorporation of values into the teaching of the subject of PE. Two professors who are experts in curriculum design participated in the workshops.

The experience was carried out in groups of four students within the framework of the teaching of the 
subject Programming and curricular design in PE teaching, and the chosen values were respect, collaboration, perseverance, equality, creativity, and honesty, which were the most prominent values in the Questionnaire and that the PASS students indicated as values that would enhance the PE subject. These values were also consistent with those indicated by the Physical Education Curriculum of the Valencian Community (Decree 87/2015). In this first workshop, each group reflected on value and anti-value and on how value was present in their lives.

In the second workshop, each group of students created four games, whose objectives, content, and developments were to promote the values selected in first workshop and used one of the games designed in practice. Once this stage was complete, hetero evaluation (by the authors) was used to objectively assess the objective, content, and development of the games; in short, to verify the degree of suitability of the stated purpose. This evaluator process was firstly performed individually by each specialist to subsequently perform a pooled analysis.

\section{Results}

Below are the most outstanding results by the students; these are presented as percentages and medians.

\section{Values that PASS students would promote in PE classes}

According to the PASS student criteria, the ten most important values that should be promoted in PE classes are respect $\left(M_{e=} 5\right)$, equality $\left(M_{e=} 5\right)$, good manners $\left(M_{e=}\right.$ 5), motivation $\left(\mathrm{M}_{\mathrm{e}=} 4\right)$, responsibility $\left(\mathrm{M}_{\mathrm{e}=} 4\right)$, group work, perseverance, class enjoyment, help, and trust $\left(\mathrm{M}_{\mathrm{e}=} 4\right)$. Table 3 shows the distribution of the respective values in percentages.

On the other hand, the values that should have the least focus, according to PASS students, are aggressiveness $\left(\mathrm{M}_{\mathrm{e}=} 0.0\right)$, authority $\left(\mathrm{M}_{\mathrm{e}=} 0.3\right)$, and daring $\left(\mathrm{M}_{\mathrm{e}=} 0.3\right)($ Table 4).

In segregating the sample by gender, of the ten values most noted by the participants, both women and men agree on the choice of the first three: equality $\left(\mathrm{M}_{\mathrm{e}=} 5\right)$, respect $\left(\mathrm{M}_{\mathrm{e}=} 5\right)$, and $\operatorname{good}$ manners (women $\mathrm{M}_{\mathrm{e}=} 5$; men $\mathrm{M}_{\mathrm{e}=}$ 4). Of the remaining six values, women selected humility $\left(\mathrm{M}_{\mathrm{e}=} 5\right)$, responsibility, motivation, group work, collaboration $\left(\mathrm{M}_{\mathrm{e}=} 4.5\right)$, empathy, and perseverance $\left(\mathrm{M}_{\mathrm{e}=}\right.$ 4). The distribution of the percentages for each value is
Table 3.

\begin{tabular}{lccccc}
\multicolumn{7}{l}{$\begin{array}{l}\text { Values to promote by the PASS student. } \\
\text { Value }\end{array}$} & $\mathrm{Ll} \%$ & $\mathrm{I} \%$ & $\mathrm{Cl} \%$ & $\mathrm{VI} \%$ & $\mathrm{EI} \%$ \\
\hline Respect & 0.0 & 0.0 & 8.1 & 24.3 & 67.6 \\
Equality & 1.4 & 4.1 & 2.7 & 24.3 & 67.6 \\
Good manners & 1.4 & 1.4 & 12.2 & 33.8 & 51.4 \\
Motivation & 0.0 & 2.7 & 16.2 & 43.2 & 37.8 \\
Responsibility & 0.0 & 2.7 & 23.0 & 40.5 & 33.8 \\
Enjoyment of the class & 0.0 & 2.7 & 29.7 & 35.1 & 32.4 \\
Teamwork & 0.0 & 5.4 & 17.6 & 45.9 & 31.1 \\
Trust & 0.0 & 4.1 & 27.0 & 29.7 & 39.2 \\
Collaboration & 0.0 & 6.8 & 27.0 & 37.8 & 28.4 \\
Perseverance & 1.4 & 2.7 & 21.6 & 43.2 & 31.1 \\
\hline
\end{tabular}

LI: less important; I: important; CI: considerably important; VI: very important; EI: extremely important.

Table 4

Values that should be least encouraged

\begin{tabular}{lccccccc}
\hline Value & $\mathrm{OV} \%$ & $\mathrm{NI} \%$ & $\mathrm{LI} \%$ & $\mathrm{I} \%$ & $\mathrm{Cl} \%$ & $\mathrm{VI} \%$ & $\mathrm{El} \%$ \\
\hline Aggressiveness & 47.3 & 18.9 & 12.2 & 6.8 & 12.2 & 0.0 & 2.7
\end{tabular}

$\begin{array}{llllllll}\text { Aggressiveness } & 47.3 & 18.9 & 12,2 & 6.8 & 12.2 & 0.0 & 2.7 \\ \text { Authority } & 0.0 & 1.4 & 12.2 & 25.7 & 35.1 & 16.2 & 9.5\end{array}$

\begin{tabular}{llllllll} 
Authority & 0.0 & 1.4 & 12.2 & 25.7 & 35.1 & 16.2 & 9.5 \\
Daring & 1.4 & 0.0 & 2.7 & 35.1 & 36.5 & 18.9 & 5.4 \\
\hline
\end{tabular}

OV: opposite value; NI: not important; LI: less important; I: important; CI: considerab

important; VI: very important; EI: extremely important.

Table 5.

Values that women participants would promote.

Values $\quad \mathrm{L} \% \quad \mathrm{I} \%$

Equality 7.1

Good manner

Respect

Humility

Responsibility

Teamwork

Motivation

Collaboration

Empathy

\begin{tabular}{lccccc} 
Perseverance & 0.0 & 0.0 & 21.4 & 35.7 & 42.9 \\
\hline LI: less important; I: important; CI: considerably important; VI: very important; EI: extremely
\end{tabular}

important.

Table 6 .

Values promoted by men participants.

Values

Equality

Respect

$\begin{array}{lll}\text { Good manners } & 1.7 & 1.7\end{array}$

$\begin{array}{lll}\text { Motivation } & 0.0 & 3.3\end{array}$

$\begin{array}{lll}\text { Trust } & 0.0 & 5.0\end{array}$

Enjoyment of the class $\quad 0.0$

$\begin{array}{lll}\text { Perseverance } & 1.7 & 3.3 \\ \text { Repon } & 0.0 & 3.3\end{array}$

$\begin{array}{lll}\text { Responsibility } & 0.0 & 3.3 \\ & 0.0 & 6.7\end{array}$

\begin{tabular}{lrr} 
Teamwork & 0.0 & 6.7 \\
\hline
\end{tabular}

Empathy

\begin{tabular}{lll}
$\mathrm{Cl} \%$ & $\mathrm{VI} \%$ & $\mathrm{El} \%$ \\
\hline
\end{tabular}

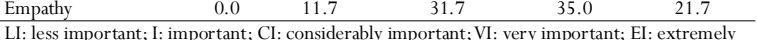

important.

Table 7.

Teachers' analysis of the games designed and developed by the students.

\begin{tabular}{|c|l|c|c|c|c|c|c|c|c|c|c|c|c|}
\hline \multirow{2}{*}{ Criteria Value } & \multirow{2}{*}{ Total Games } & \multicolumn{3}{|c|}{ Objective } & \multicolumn{3}{c|}{ Content } & \multicolumn{3}{c|}{ Development } \\
\cline { 3 - 11 } & E & G & IS & P & E & G & IS & P & E & G & IS & P \\
\hline
\end{tabular} \begin{tabular}{l|c|c|c|c|c|c|c|c|c|c|c|c|c}
\hline Collaboration & 8 & 5 & 1 & 0 & 2 & 4 & 2 & 0 & 2 & 4 & 2 & 0 & 2
\end{tabular} \begin{tabular}{l|l|l|l|l|l|l|l|l|l|l|l|l|l} 
Creativity & 8 & 4 & 2 & 1 & 1 & 4 & 2 & 0 & 2 & 4 & 2 & 0
\end{tabular}

Perseveran

Respect

Equality

TOTAL

E: excel

shown in Table 5.

On the other hand, men pointed to motivation, trust, enjoyment of the class, perseverance, responsibility, and group work $\left(M_{e=} 4\right)$. The percentage distribution is expanded in Table 6.

When analyzing gender data through the MannWhitney U statistic, we observed significant differences in three values: humility $(\mathrm{U}=259.500, p=0.040$; $<0.05)$, group work $(\mathrm{U}=264.50 p=0.020 ;<0.05)$ and empathy $(\mathrm{U}=248.000, p=0.044 ;<0.05)$, to which women gave more importance.

Teaching-learning assessment for the promotion of values in $P E$

The students designed and created 16 games to 
promote the values of collaboration and creativity in PE. Twelve of them met the requirements of adequacy for the proposed purpose, and the remaining four of them did not sufficiently adapt the objectives, content, or development. In addition, of the 16 games developed to promote the values of honesty and perseverance, 8 embodied the requirements, and the remaining 8 games did not fit the stated purposes. Finally, of the 16 games related to the development of the values of equality and respect, only 4 of them met the demands raised, while the rest of the games did not fulfill the purposes of the activity. Table 7 shows the results of the game analysis.

\section{Discussion}

The objectives of this study were to identify what values would enhance PASS's initial training of students in these classes and to design teaching-learning strategies for the promotion of values in the subject of PE.

If value is a construct developed from the cognitive representation of a goal—which Rokeach (1973) calls «needs», and Schwartz (1994) categorizes as universal requirements or guides - then the values represent the intensity levels and priorities that are assigned to these needs, requirements, or universal guides.

Royal Decree 1105/2014, in relation to the subject of PE in Compulsory Secondary Education and the Baccalaureate, notes that the integral training of students through civic and moral development is intended to be achieved by including a specific block of content directly related to cross-cutting elements. This block of content refers to social inclusion, empathy, collaboration, teamwork, respect, responsibility, and tolerance.

In our study, the values that would promote a future as professionals in physical and sporting activity are the individual values of respect and good manners and the socio-individual or mixed value of equality, which constitute the basis for the integral formation of a person and are acquired, first, in the family context (Gázquez, Pérez, Carrión, Luque de la Rosa, \& Molero, 2015). These results also match those obtained in a study by Tolino, Mínguez, and Hernández (2009), where parents referred to respect and good manners as basic values in the family. Students also more strongly emphasized motivation, group work, perseverance, enjoyment of the class, help, and trust—values related to the nature of physical activity and sport that allude to a greater dynamism of the class and the deployment of competencies related to the psychosocial field of the person (Vega \& Ávalos, 2017).

It is striking that students did not distinguish, in addition to equality, other social values such as tolerance, justice, and freedom, fundamental in sports practice (Madrid et al., 2016), and individual values such as discipline, basic in sport; aggression, understood as one's drive and decision to undertake a task; authoritysubstantive and inherent - that arises from relations focused on respect and admiration for others (MermaMolina \& Gavilán, 2019); daring, that is, boldness or courage to act; individual identity (self-concept and selfesteem); or social identity that is built in relation to others and which derives from the knowledge and belonging of the person to a group (Tajfel, 1981). In addition, other values directly linked to the area of PE, such as responsibility, group work, perseverance, enjoyment of the class, collaborative work, and trust (Madrid et al., 2016; Monjas, et al., 2015), were considered by the students as being secondary. This fact may be related, as we have mentioned previously, is the limited knowledge and experience of teachers in didactics of moral and social development, leaving values education within the scope of the hidden curriculum (Jacobs et al., 2013; Thornberg, 2008).

If gender-motivated differences are considered, it should be noted that the value of humility would be promoted exclusively by women in PE classes, and the values of trust and enjoyment of the class would be developed exclusively by men. These findings are consistent with Barberá's studies (2009), which concluded that women emphasize traits more related to kindness, understanding, and awareness of others' feelings, while men emphasize competition, active traits, and physical strength. If PASS students put this axiological thinking into practice in their future professional performance, the subject of PE would be another instrumental element for the internalization of gender stereotypes in society, since it would continue to promote the logic of obedience, submission, acceptance, care, and affection in the social construction of femininity and the logic of dominance, enjoyment, competition, and control in the social construction of masculinity (Rebollo-Catalán, Ruiz-Pinto, \& GarcíaPérez, 2017).

By analyzing the design of the games developed by students, it was concluded that it is more feasible for students to implement activities that promote the values of collaboration and creativity, since these are traditionally more linked to the essence of physical and sporting activity. The same is not true of the values of 
equality, perseverance, respect, aggressiveness, authority, and daring; despite them being present in sports activities, they are not easy to focus upon in the objective set. This may be related to a possible lack of curriculum content linked to moral and social development in the initial training of PE teachers (Jacobs et al., 2013). Our results also confirm the position of Johansson, Emilson, and Puroila (2018), who reported that the learning of values must be built between theory and practice, developing its own language that serves as the basis for future professionals in identifying the different actions and values that these actions transmit.

In order for genuine value education to occur, physical and sporting activity must be considered in a way that allows, first, the promotion of self-knowledge and improved self-concept, and then enhances dialogue for conflict resolution; promotes personal autonomy, respect, tolerance, and acceptance of individual differences; and takes advantage of situations of play, training, and competition to work on social skills aimed at fostering coexistence (Derri, Kellis, Vernadakis, Albanidis, \& Kioumourtzoglou, 2014).

This study is expected to contribute to better initial training in the acquisition of professional skills that promote value education, and this does not fall within the scope of the hidden curriculum (Thornberg, 2008). To this end, we support the positions of Metzler (2011) and Sánchez et al. (2019) in the proposal of a teaching model focused on personal and social responsibility, which could be useful for training in values in PE classes.

One of the limitations that this study had is gender bias, since there is little enrollment of women in the degree of Physical Activity and Sports Sciences. So, this study could be extended to other geographic and educational contexts to expand the sample by gender.

\section{Conclusions}

PE can be a favorable context for promoting and developing both personal and social values in students. Identification of the values displayed by students showed that the values inherent in physical activity, such as collaboration, tolerance, and empathy, were not easily identified. In addition, some values that university students would promote in PE classes are related to the values that are acquired in the family nucleus. The scarcity and types of values that perpetuate traditional gender roles, highlighted by students, show that the university education of future PASS teachers should be focused on the conscious integration of values into the teaching of PE. In this process, the use of learning as a key methodology to bring students closer to the reality of the classroom is essential.

\section{References}

Abella, V., Lezcano, F., \& Casado, R. (2017). Avaliação da hierarquia de valores humanos de Schwartz na adolescência: gênero e implicações educacionais. Revista Brasileira de Educação, 22(68), 123-146. doi:10.1590/s141324782017226807

Agúndez, D. (2015). Educar en valores. Supervisión 21. Revista de Educación e Inspección, 37, 1-36.

Ávalos, M. A., Martínez, M. A., \& Merma, G. (2015). La pertinencia educativa de las habilidades gimnásticas. Apunts: Educació Física i Esports, 121(3), 28-35.

Baker, W. E. (2005). America's crisis of values: Reality and perception. Princeton: University Press.

Balcázar, A. (2021). El campamento educativo como escenario para el fortalecimiento de habilidades sociales. Retos. Nuevas Tendencias en Educación Física, Deporte y Recreación, 41, 143-152.

Barberá, E. (2009). Perspectiva sociocognitiva: Estereotipos y esquemas de género. In E. Barberá, \& I. Benlloch (Coord.), Psicología y género (pp. 5580). España: Prentice Hall.

Beni, S., Fletcher, T., \& Ní Chróinín, D. (2017). Meaningful experiences in physical education and youth sport: A review of the literature. Quest, 69(3), 291-312. doi:10.1080/00336297.2016.1224192

Bergdahl, L. (2006). About common values in a pluralistic society: Teacher educators' view on and work with common values in the new teacher education. Journal of Research in Teacher Education, 13, 17-39.

Brunelle, J., Danish, S. J., \& Forneris, T. (2007). The impact of a sport-based life skill program on adolescent prosocial values. Applied Developmental Science, 11(1), 43-55.

Decreto 87/2015, de 5 de junio, del Consell, por el que establece el currículo y desarrolla la ordenación general de la Educación Secundaria Obligatoria y del Bachillerato en la Comunitat Valenciana. Diario Oficial de la Generalitat Valenciana núm. 7544 de 10.06.2015. Ref. 005254/2015.

Derri, V., Kellis, I., Vernadakis, N., Albanidis, E., \& Kioumourtzoglou, E. (2014). The effect of an intercultural Physical Education Program in comparison to the typical one on students' social skills learning. Journal of Human Sport \& Exercise, 9(1), 91 - 
102. doi:10.4100/jhse.2014.91.10

Escartí, A., Buelga, F., Gutiérrez, M., \& Pascual, C. (2009). El desarrollo positivo a través de la actividad física y el deporte: El programa de responsabilidad personal y social. Revista de Psicología General y Aplicada, 62(1-2), 45-52.

Escartí, A., Wright, P., Pascual, C., \& Gutiérrez, M. (2013). Observación de las estrategias que emplean los profesores de educación física para enseñar responsabilidad personal y social. Revista de Psicología del Deporte, 22, 159-166.

Frånberg, G. M. (2006). Teacher students' perception of the foundation of values in the teacher education. Journal of Research in Teacher Education, 13, 125-169.

Gázquez, J. J., Pérez, M. C., Carrión, J. J., Luque de la Rosa, A., \& Molero, M. (2015). Perfiles de valores interpersonales y análisis de conductas y actitudes sociales de adolescentes. Revista de Psicodidáctica, 20(2), 321-337. doi: 10.1387/RevPsicodidact. 12978

Gutiérrez, M., Escartí, A., \& Pascual, C. (2011). Relaciones entre empatía, conducta prosocial, agresividad, autoeficacia y responsabilidad personal y social de los escolares. Psicothema, 23(1), 13-19.

Hartmann, D., Sullivan, J., \& Nelson, T. (2012). The attitudes and opinions of high school sports participants: An exploratory empirical examination. Sport Education and Society, 17(1), 113-132. doi:10.1080/13573322.2011.607915

Hellison, D., \& Martinek, T. (2006). Social and individual responsibility programs. In D. Kirk, D. Mcdonald, \& M. O'Sullivan (Eds.), The handbook of physical education (pp. 610-626). CA: Sage. Thousand Oaks.

Jacobs, F., Knoppers, A., \& Webb, L. (2013). Making sense of teaching social and moral skills in physical education. Physical Education and Sport Pedagogy, 18 (1), 1-14.doi:10.1080/ 17408989.2011.621118

Johansson, E., Emilson,A., \& Puroila,A. (2018). Mapping the field: What are values and values education about? In E. Johansson, A. Emilson, \& A. Puroila (Eds.), Values education in early childhood settings (pp. 13-31). Cham: Springer.

Larson, R. W. (2000). Toward a psychology of positive youth development. American Psychologist, 55, 170 183.

Larson, A., \& Silverman, S. J. (2005). Rationales and practices used by caring physical education teachers. Sport, Education and Society, 10(2), 175-94.

Lee, M. J., Whitehead, J., Ntoumanis, N., \& Hatzigeorgiadis, A. (2008). Relationships among values, achievement orientations, and attitudes in youth sport. Journal of Sport and Exercise Psychology, 30(5), 581-610.

Madrid, P., Prieto, A., Samalot, A., \& Gil, P. (2016). Evaluación de una propuesta extraescolar de conductas apropiadas en educación física y deportiva. Retos. Nuevas Tendencias en Educación Física, Deporte y Recreación, 30, 36-42.

Mahoney, J. L., Larson, R. W., Eccles, J. E., \& Lord, H. (2005). Organized activities as developmental contexts for children and adolescents. In J. L. Mahoney, R. W. Larson, \& J. S. Eccles (Eds.), Organized activities as contexts of development:

Extracurricular activities, after-school, and community programs (pp. 3-22).Mahwah, NJ: Lawrence Erlbaum Associates.

Martínez, R., Cepero, M., Collado, D., Padial, R., Pérez, A., \& Palomares, J. (2014). Adquisición de valores y actitudes mediante el juego y el deporte en Educación Física, en Educación Secundaria. Journal of Sport and Health Research, 6(3),207-216.

McHale, J. P., Vinden, P. G., Bush, L., Richer, D., Shaw, D., \& Smith, B. (2005). Patterns of personal and social adjustment among sport-involved and noninvolved urban middle-school children. Sociology of Sport Journal, 22, 119-136. doi:10.1123/ssj.22.2.119 Merma-Molina, G., \& Gavilán, D. (2019). Análisis de las valoraciones del alumnado para repensar la autoridad docente y la formación para la ciudadanía. Educatio Siglo XXI, 37(1), 55-72. doi:10.6018/ educatio. 363381

Metzler, M. W. (2011). Instructional models for Physical Education. Scottsdale, AZ: Holcomb Hathaway.

Mikalsen, H., \& Lagestad, P. (2020). Adolescents' meaning-making experiences in physical educationin the transition from primary to secondary school. Sport, Education and Society, 25(7), 802-814. doi:10.1080/13573322.2019.1662389

Molina, M., Gutiérrez, D., Segovia, Y., \& Hopper, T. (2020). El modelo de Educación Deportiva en la escuela rural: Amistad, responsabilidad y necesidades psicológicas básicas. Retos. Nuevas Tendencias en Educación Física, Deporte y Recreación, 38, 291-299.

Monjas, R., Ponce, A., \& Gea, J. M. (2015). La transmisión de valores a través del deporte. Deporte escolar y deporte federado: Relaciones, puentes y posibles trasferencias. Retos. Nuevas Tendencias en Educación Física, Deporte y Recreación, 28, 276-284.

Núñez, I., \& Bermúdez, E. (2019). Values, University Social Responsibility (USR), Education for 
Sustainable Development (ESD) and Organizational Communication Management. Revista Internacional de Gestión del Conocimiento y la Tecnología, 7(1), 104115.

Prat, Q., Camerino, O., Castañer, M., Andueza, J., \& Puigarnau, S. (2019). El model pedagògic de responsabilitat personal i social com a motor d'innovació en educació física. Apunts. Educació Física i Esports, 2(136), 83-99.

Real Decreto 1105/2014, de 26 de diciembre, por el que se establece el currículo básico de la Educación Secundaria Obligatoria y del Bachillerato. Boletín Oficial del Estado. 03.01.2015, núm. 3. BOE-A-201537.

Rebollo-Catalán, A., Ruiz-Pinto, E., \& García-Pérez, R. (2017). Preferencias relacionales en la adolescencia según el género. Revista Electrónica de Investigación Educativa, 19(1), 58-72. doi:10.24320/ redie.2017.19.1.1022

Rokeach, M. (1973). The nature of human values. New York: Free Press.

Rubio-Rodríguez, G., Hernández, L., \& Varón, N. (2019). Validación de un cuestionario para evaluar valores personales y sociales en jóvenes deportistas. Retos. Nuevas Tendencias en Educación Física, Deporte y Recreación, 36, 152-158.

Ruiz, L. M., Rodríguez, P., Martinek, T., Schilling, T., Durán, L. J., \& Jiménez, P. (2006). El proyecto esfuerzo: Un modelo para el desarrollo de la responsabilidad personal y social a través del deporte. Revista de Educación, 143, 933-958.

Sánchez-Alcaraz, B. J., López-Jaime, G., ValeroValenzuela, A., \& Gómez-Mármol, A. (2017). Los programas de educación en valores a través de la educación física y el deporte. Actividad Física y Deporte, Ciencia y Profesión, 28(25), 45-58.

Sánchez, B., Gómez, A., Valero, A., De la Cruz, E., Moreno, J., \& Lochbaum, M. (2019). Teachers' perceptions of personal and social responsibility improvement through a physical education based intervention. Journal of Physical Education and Sport, 19, 156-161. doi:10.7752/jpes. 2019.s1023

Sánchez, D., Leo, F. M., Sánchez, P. A., Gómez, F. R., \& García, T. (2011). Teoría de autodeterminación y comportamientos prosociales en jóvenes jugadores de fútbol. Apunts: Educación Física y Deportes, 108(1), 32-38.

Sandford, R. A., Armour, K. M., \& Duncombe, R. (2007). Physical activity and personal/social development for disaffected youth in the UK. In N.
L Holt (Ed.), Positive youth development through sport international studies in Physical Education and youth sport, (pp. 97-109). Routledge: London and New York.

Schwartz, S. H. (1992). Universals in the content and structure of values: Theoretical advances and empirical tests in 20 countries. Advances in Experimental Social Psychology, 25, 1-65.

Schwartz, S. H. (1994). Are there universal aspects in the structure and contents of human values? Journal of Social Issues, 50(4), 19-45.

Schwartz, S. H. (2012). An overview of the Schwartz theory of basic values. Online Readings in Psychology and Culture, 2(1), 2307-0919. doi:10.9707/23070919.1116

Schwartz, S. H., \& Bilsky, W. (1990). Toward a theory of the universal content and structure of values: Extensions and cross-cultural replications. Journal of Personality and Social Psychology, 58(5), 878-891.

Smith, A. L. (2003). Peer relationships in physical activity contexts: A road less traveled in youth sport and exercise psychology research. Psychology of Sport and Exercise, 4, 25-39. doi:10.1016/S1469. 0292(02)00015-8

Tajfel, H (1981). Social identity and intergroup relations. London: Cambridge University Press.

Thornberg, R. (2008). The lack of professional knowledge in values education. Teaching and Teacher Education, 24(7), 1791-1798.

Tolino, A., Mínguez, R., \& Hernández, M. A. (2009). Análisis empírico-descriptivo de los valores de padres y profesores en las pedanías de Cartagena y Torre Pacheco. In II Jornadas de los Máster en Investigación e Innovación en Educación Infantil y Educación Primaria. Murcia: Universidad de Murcia.

Vega, L., \& Ávalos, M. A. (2017). Desarrollo de competencias profesionales en Educación Física: Una experiencia temprana de observación en contextos reales. In M. L. Gravini, J. C. Marín, \& S. A. Falla (Coord.), Aportes a la calidad educativa desde la investigación (pp. 255-267). Colombia: Universidad Simón Bolivar.

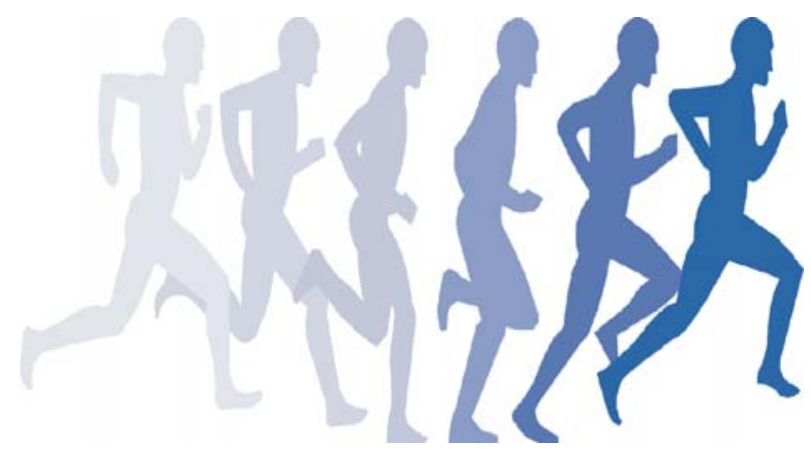

